\title{
Considerations related to the mapping of Romanian anthroponyms and toponyms ${ }^{\dagger}$
}

\author{
Ionel Boamfă* \\ Faculty of Geography and Geology, "Alexandru Ioan Cuza" University, Bd. Carol I 11, 700506 Iași, Romania
}

\begin{abstract}
Article info
History:

Received July 19, 2018

Accepted August 26, 2018

Published October 7, 2018

Key words:

toponym

anthroponym

mapping

Romanian space

Abstract

The article tries to highlight some aspects related to the mapping of toponyms and anthroponyms, in the Romanian space and also at a larger level (European, world). In the case of the toponyms we highlighted the repartition of oikonyms with the suffixes -ești, -eni/-ani, -ari, -ovți/-evți,-inți in the Romanian space. This space includes the present territory of Romania and Republic of Moldova and the regions of Ukraine, Bulgaria and Hungary that belonged temporarily to the Romanian state. The Romanian suffixes -ești,-eni/-ani, -ari appear more frequently, the most important being the first. For the mapping of the anthroponyms we presented only the mapping of the repartition of names with the suffix -escu, at the world level, by countries. This suffix appears most frequently in Romania and/or in the Republic of Moldova.
\end{abstract}

\section{Introduction}

We intend to highlight several aspects related to the mapping of the anthroponyms and toponyms, at all scales of analysis. Among these aspects, we mention the selection of a "unitary" administrative division, conventionally fixed, for all the analysed periods (for the comparison of data), and the fact that, although we do not have access to all anthroponymic information, if before and after an interval when the documented occurrence was below the average we have information that proves the high frequency of a name, it is possible for the anthroponym to have an above-average presence during the interval in question (having, in this situation, either an incomplete access to anthroponymic data, or incomplete published data), etc. For the Romanian space, to which we refer in particular, we will utilize-strictly conventional, for the comparability of spatial and temporal data-a map, at the communal level, that includes the present communes of Romania, Republic of Moldova, and of the territories of Hungary, Bulgaria and Ukraine, that had belonged to the Romanian state.

\section{Research methodology. Problems}

For doing this, we have used some methods, grouped in two categories: methods of collecting data, and methods of analysing and interpreting the information. Among the collecting methods (sources of information) we used the dictionaries of localities, the censuses of population, the topographic mapsfor the inventory of toponymic information (the names of localities) -, and related to the collection of Romanian family names, at the World level, the site forebears. $i^{1}$.

As methods of analysis and interpretation we used the statistic method, with the aid of which the data are introduced in the computer, in a Microsoft Excel file, after which the data are prepared, either

\footnotetext{
†This paper was presented at the symposium “Toponymy between history, geography and linguistics”, Iași, May 10, 2018.

*Email address: ionel_boamfa@yahoo.com.

${ }^{1}$ The students of the promotions 2017 and 2018, from the fields of Geography of Tourism and Geography of Tourism French branch, from the Faculty of Geography and Geology of the "Alexandru Ioan Cuza" University of Iași have contributed to the introduction in the computer of the data related to the number of bearers of analysed names.
} 
in percentages, or by calculating the spatial distribution coefficient ${ }^{2}$. Afterwards, we used the mapping method, for making the maps, with the Philcarto software. The maps are realised in palettes of colours, either using the percent data or the calculated data for the spatial distribution coefficient. The maps were made with the Adobe Illustrator programme.

In the course of this activity we solved several problems. The first problem is about the information related to the names of localities. A part of these names (for example, in Romania) are an official creation of the Romanian administration (especially in Transylvania). This required the verification of the initial form of name, and, if the actual name, containing one of the analysed suffixes, had an official character, the name was not included in analysis.

Second, for the representation of the data, we did not have, initially, a base map for the entire Romanian space. Starting from the base map of Romania at the communal level (that had must be actualised), in which we added the base map of the Republic of Moldova at the same level, we created the contour of the other communal administrative units from Hungary, Bulgaria and Ukraine (Fig. 1).

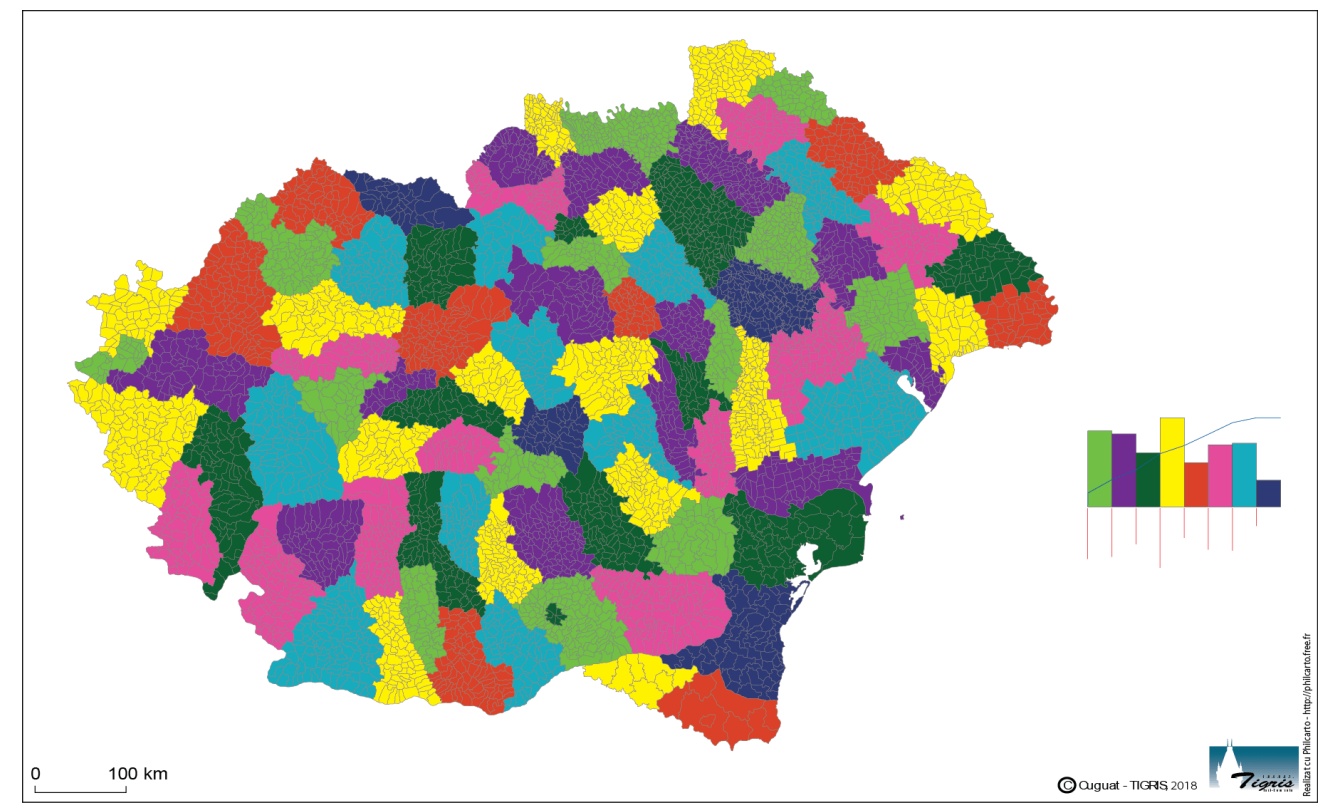

Figure 1: România - basic map at communal level.

Finally, we used the data for the family names from the site forebears.io for the United Kingdom of Great Britain and Northern Ireland, which are (re)presented at the level of administrative entities: England, Wales, Scotland and Northern Ireland. Consequently, the data were summed up at the level of the entire Kingdom.

\section{Cartographic representation of toponyms and anthroponyms}

For the cartographic representation of different onomastic elements (toponyms, anthroponyms) we referred to the mapping of the names of localities (oikonyms). We stopped, for instance, only at those that are related to the development of the localities from patriarchal communities of free peasants (Romanian:

\footnotetext{
${ }^{2}$ This coefficient result after the division of the percent of bearers of name in an administrative entity (commune, county, region, country, etc.) to the percent of population of the same entity. At the level of the analysed zone, the value of coefficient are 1 (equal with the $100 \%$ percent of bearers of name, given by the sum of percentages of all administrative entities, divided at $100 \%$, the sum of percentages of population of the same entities). At consequence, we have, theoretically, three situations: a) in which the spatial distribution coefficient are over 1 , that signify that the name is overrepresented, by rapport of average; $b$ ) this coefficient are below 1 , that signify that a name are underrepresented by rapport of average, and c) coefficient equal with 1 , a situation that we not retrieved yet.
} 
obștițărăneşti), a process marked in onomastics by the use of characteristic suffixes, either Romanian (-eşti, -enil-ani, -ari) or Slavic (-ovți/-evți, -inți) (see Ungureanu, 2006, p. 68, 130 and Moldovanu, 1970, p. 19).

A large analysis of the formation laws of this was realised by Dragoș Moldovanu (1970). Another book, Tezaurul Toponimic al României. Moldova, volume II, part I (2014) includes a rich toponymic index, related to the same oikonymic elements. We focused on the spatial distribution of this, only related to the geographical repartition of the names of actual settlements, but, in perspective we will intend to analyse the disappearing localities too.

In the map below, we have represented, in percentages, the distribution of all names of localities that have one of these suffixes ${ }^{3}$. In the first map, this information is represented at the county level (Fig. 2). It is a more general level, but that offers the advantage of highlighting the spatial continuities or discontinuities of an object, process or phenomenon. Between the 18280 settlement from Romanian space, about 4000 (3934, representing 21.5\%) have in the composition of her name a such suffix. The most compact concentrations are observed in the Moldavian counties, in both parts of the Prut River, especially in the northern and central part. In the south of the country, such concentrations can be observed especially in the counties situated in the vicinity of Southern Carpathians, in the West of Muntenia and in Oltenia. As a result of an historical evolution, that had linked this regions, more time, to foreign influences-Hungarian and / or (Austrian-)Hungarian-, Transylvania have a more reduced frequency of such oikonyms, but, isolated, there are areas with a notable presence of this—the zone of the Apuseni Mountains.

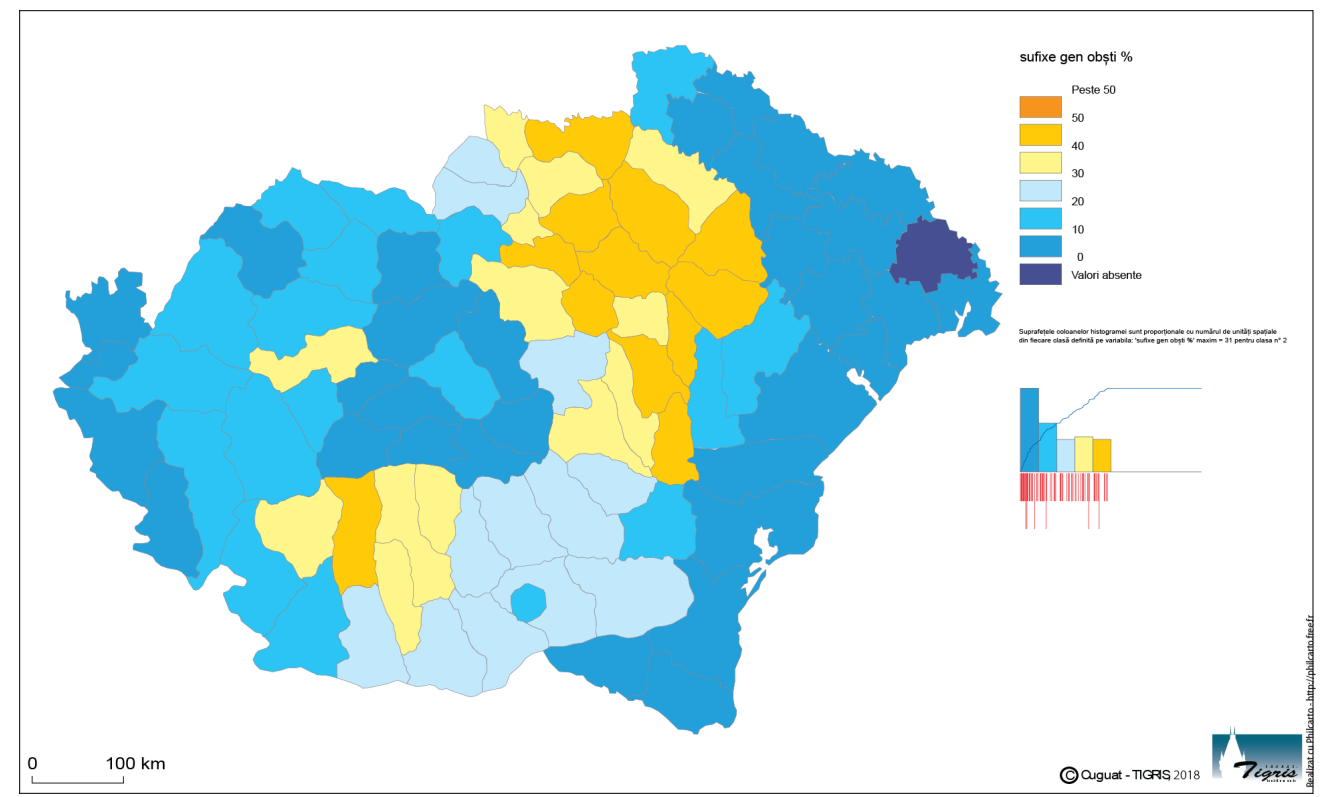

Figure 2: Distribution by counties of oikonyms with suffixes showing the development of settlements from communities of free peasants in the Romanian space (-ești, -eni/-ani, -ari, -ovți/-evți, -inți).

If we detail the level of (re)presentation at the communal level, the situation is not very changed, but this level it presents the advantages of most evidential details. The most significant concentrations of these suffixes is remarked in Central and Northern Moldavia, at the East and West of the Prut River, and in the mountainous, hill and plateau zones of Muntenia and Oltenia. The details highlight West of Carpathians more areas-not very extended, but numerous - with the presence of such oikonyms. Alongside of the Apuseni area, we can enumerate the Mountainous Banat, the Maramureș, the South of Ardeal, etc. (Fig. 3).

We can detail the analysis, first about the ethnic context-Romanian or Slavic-that imprint the suffixation. The names with Romanian suffixes (-ești, -eni/-ani or -ari) represent the great majority

\footnotetext{
${ }^{3}$ The calculation of these percentages is made within the rapport between the number of names of settlements that have this suffix and the total of localities for each commune.
} 
of these oikonyms: 3694 (20.2\%), and only 240 have Slavic suffixes. Regarding the spatial distribution, these are, in general, almost identical with those that comprise the total of oikonyms with such suffixes (Fig. 4).

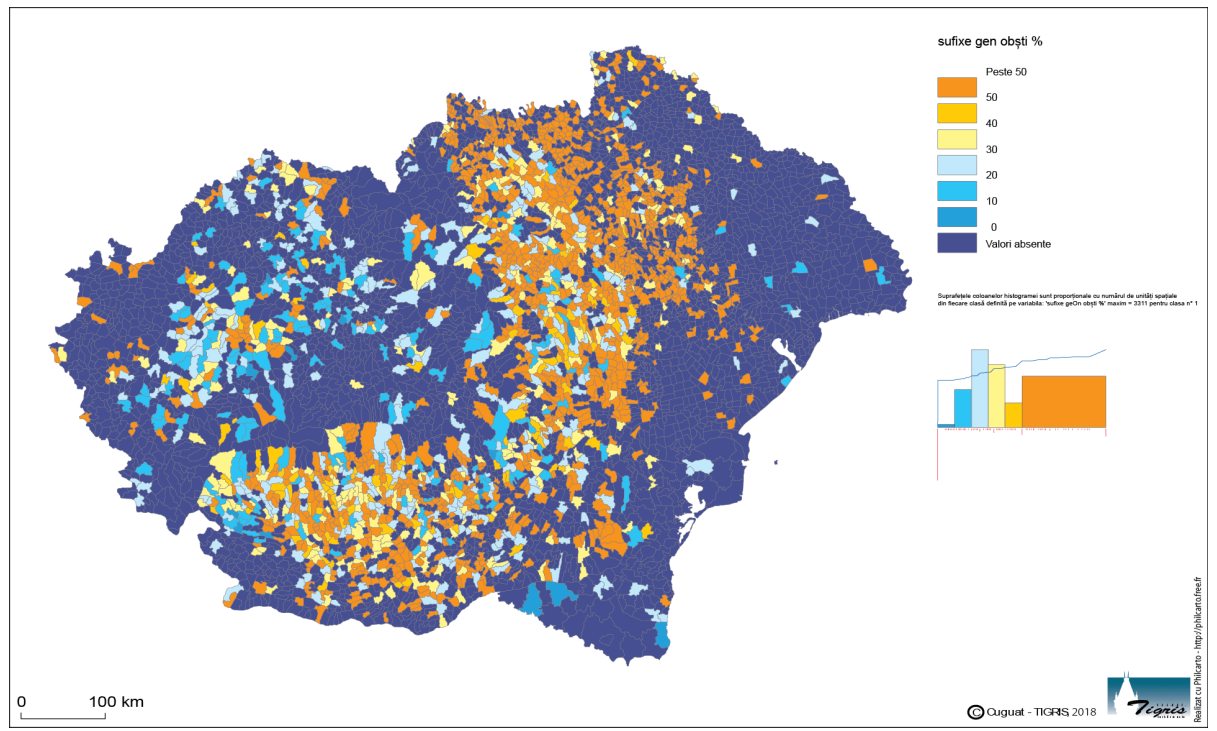

Figure 3: Distribution by counties of oikonyms with suffixes showing the development of settlements from communities of free peasants in the Romanian space (-ești, -eni/-ani, -ari, -ovți/-evți, -inți).

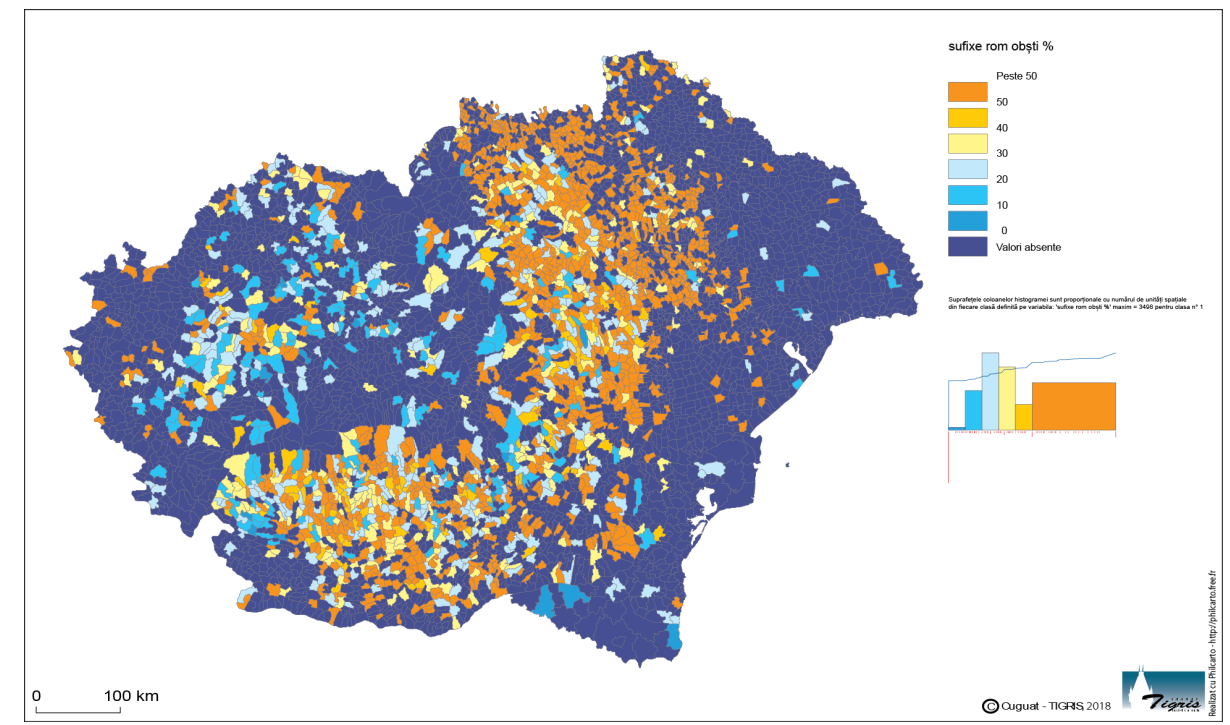

Figure 4: Distribution by counties of oikonyms with suffixes showing the development of settlements from communities of free peasants in the Romanian space (-ești,-eni/-ani,-ari).

The toponyms with the suffixes with Slavic origin are a modest percentage (only $1.3 \%$ ). The spatial repartition is limited only to the northern extremity of Romanian space (the North of Bukovina and of Bassarabia), with an isolated presence in the rest of the country (in the South of Moldavia, in Banat or Maramureş)—Fig. 5.

We can speak, shortly, about each of these suffixes. Between the more of $20 \%$ names with Romanian suffixes, the best represented is the suffix - ești-13.1\% (2403 settlements). It is a very old suffix (considered Latin or even Thracian), which explains its having the highest frequency at the level of oikonyms related to the old communities of free peasants. We do not claim to have clarified these aspects, but we think that there are numerous reasons to take into consideration the opinion of Thracian origin of the 
suffix - ești, that derived from an -isk, based on a series of numerous oikonyms registered in Antiquity in the Carpathian-Balkan space inhabited by Thracian-Dacians (Romanised in a great part and transformed in the Romanians). Such toponyms have a large extension, from Hungary and Croatia, to the South of Balkan Peninsula and are attested even in the areas north of the Danube, in Banat, Muntenia and in the South of Bassarabia.

Moreover, we can add that the same suffix -isc/-isk was used for the creation of some anthroponyms, by the Thracians entered in the process of Romanisation in the III-VI centuries (Fig. 6). We mention the existence of many inhabitants-bishops or even Roman emperors (with Thracian origin) - that bear the name Basiliscus, a derivation from Basilius ${ }^{4}$.

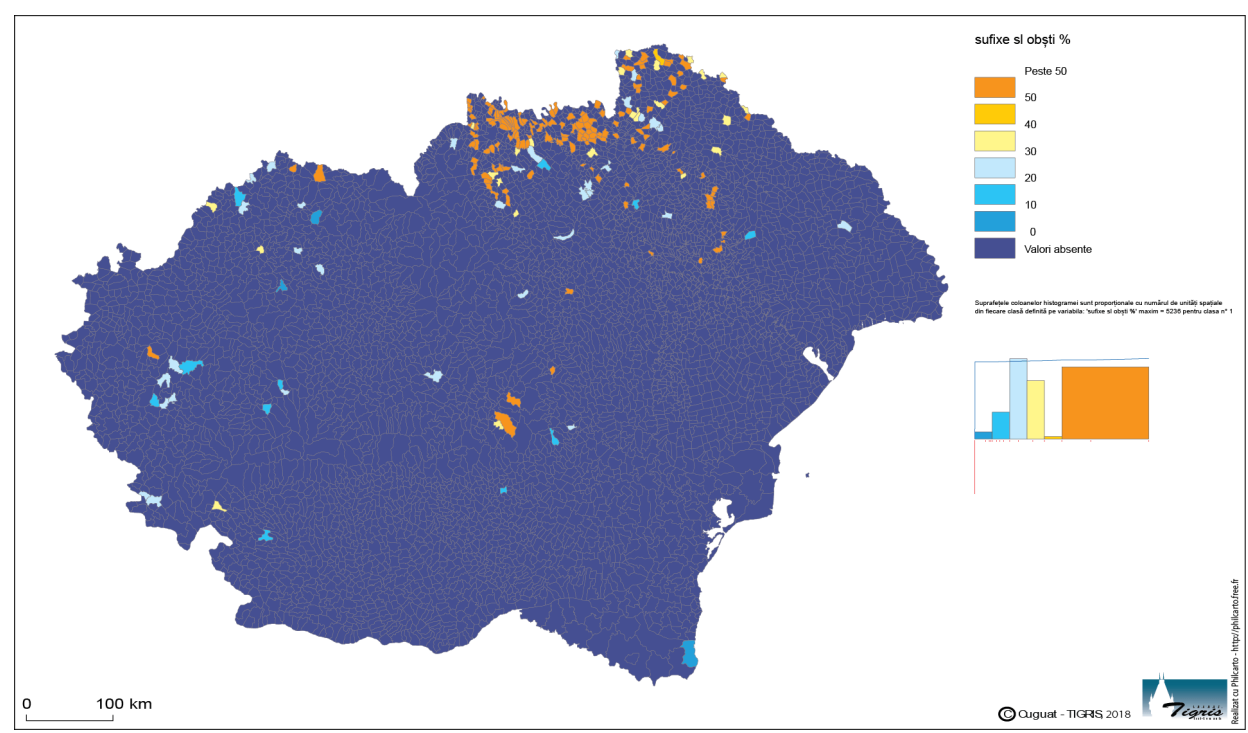

Figure 5: Distribution by counties of oikonyms with suffixes showing the development of settlements from communities of free peasants in the Romanian space (-ovți/-evți, -inți).

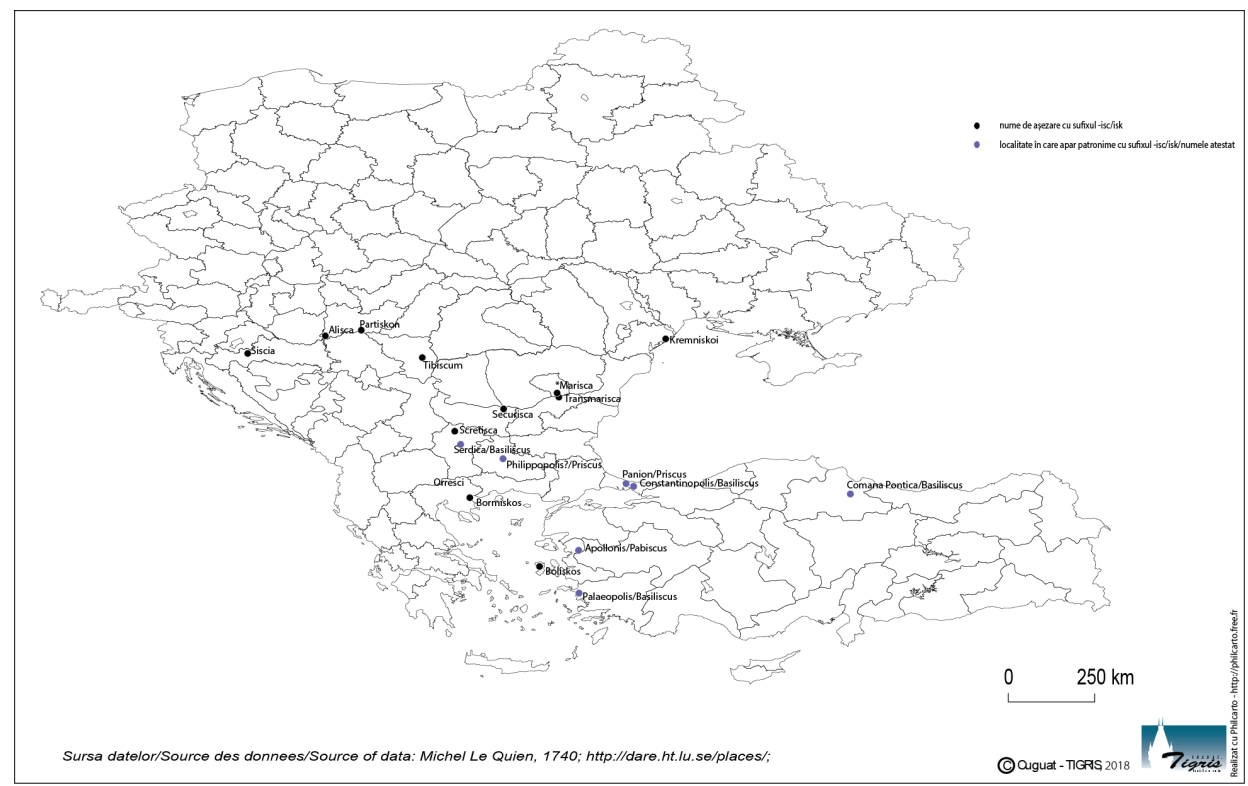

Figure 6: Distribution of toponyms and anthroponyms with the suffix -isc/-isk in the Carpathian-Balkan space.

\footnotetext{
${ }^{4}$ If, in Romanian, Basilius evolved to Vasile, Basiliscus can be the "ancestor" of Vasilescu. A proof of using by the ThracianRomans of the name Basiliscus is the mention that a bearer of name, attested as Roman emperor, was the son of the emperor Leo I the Thracian.
} 
In the present, the geographical repartition of the oikonyms with this suffix highlight the same zones, in all of the three Romanian historical provinces: Moldavia, Wallachia and Transylvania (Fig. 7).

If, on the other hand, we refer to the suffixes -enil-ani, the number and the percentage are more modest: 675 localities (3.7\%). These appear more frequent in Moldavia, long of the Prut and especially East of this river. This names not are absent in other regions, but her frequency are more modest, that can observe in Fig. 8.

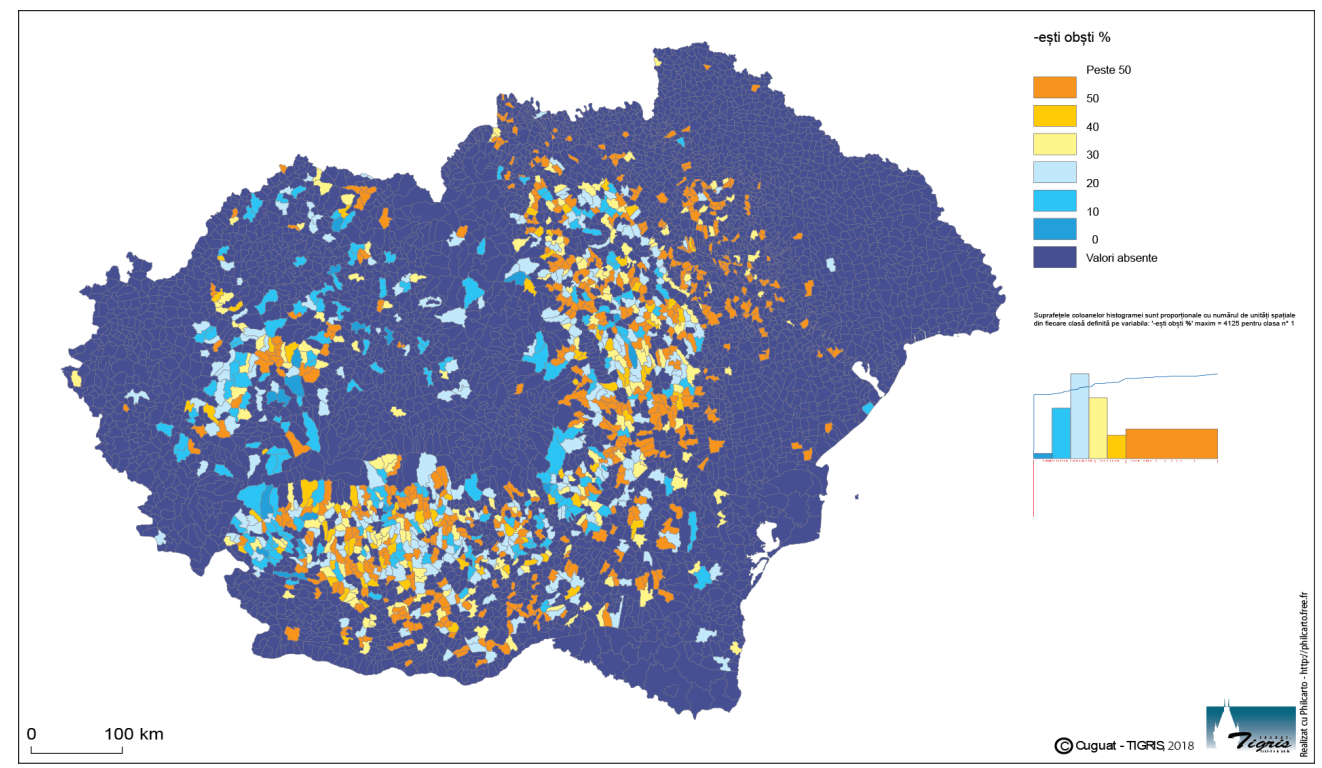

Figure 7: Distribution by counties of oikonyms with the suffix - $e s ̧ t i$, showing the development of settlements from communities of free peasants in the Romanian space.

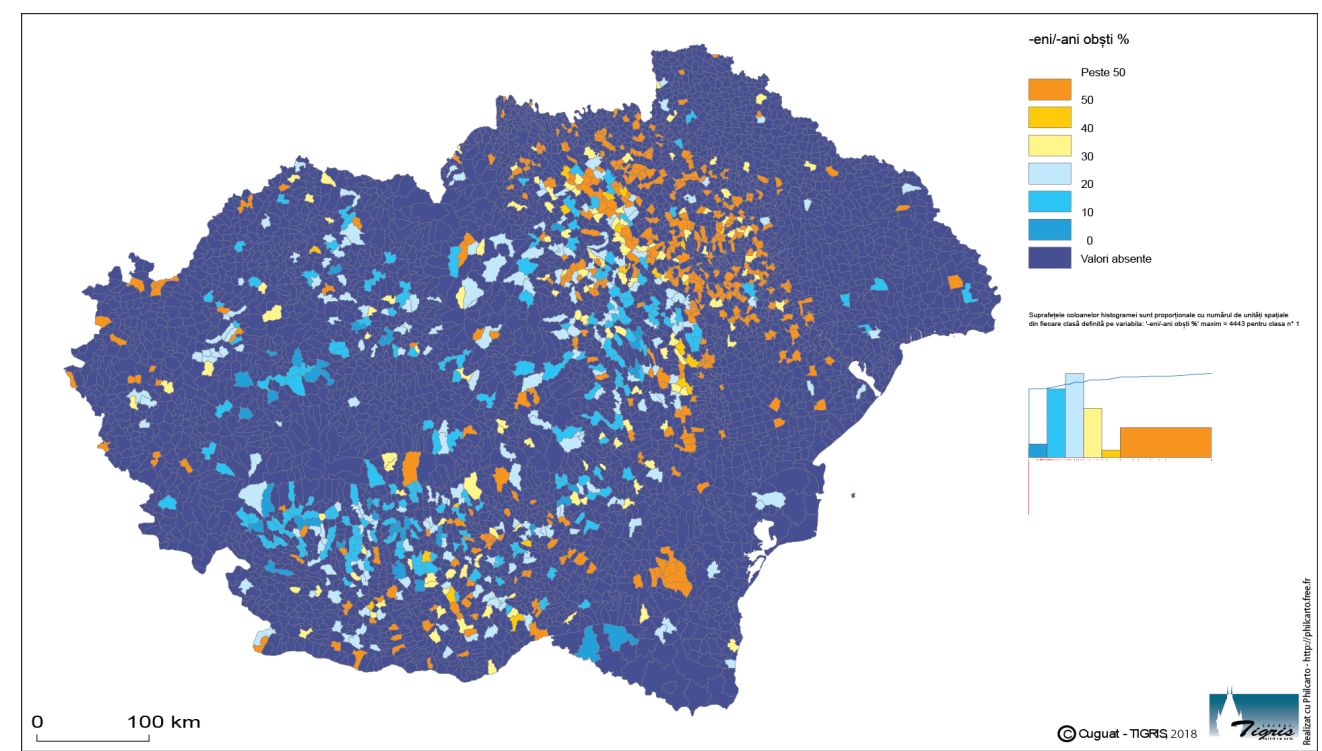

Figure 8: Distribution by counties of oikonyms with the suffixes -eni/-ani, showing the development of settlements from communities of free peasants in the Romanian space.

More isolate is the suffix -ari, with social role. We have register only 26 such oikonyms, localised, in the North and South-West of Moldavia and in Banat (Fig. 9).

Between the Slavic suffixes, the most frequent are -ovți/-evți. These are in composition of 180 settlements (1\%), concentrated, more compact, in Bukovina and in the North of Bassarabia, in which are present long of the Nistru River, and in Transnistria (especially in the north part of region). Other isolated 
areas are located in the South-West of Moldavia, and in the South-East and North-West of Transylvania (Fig. 10).

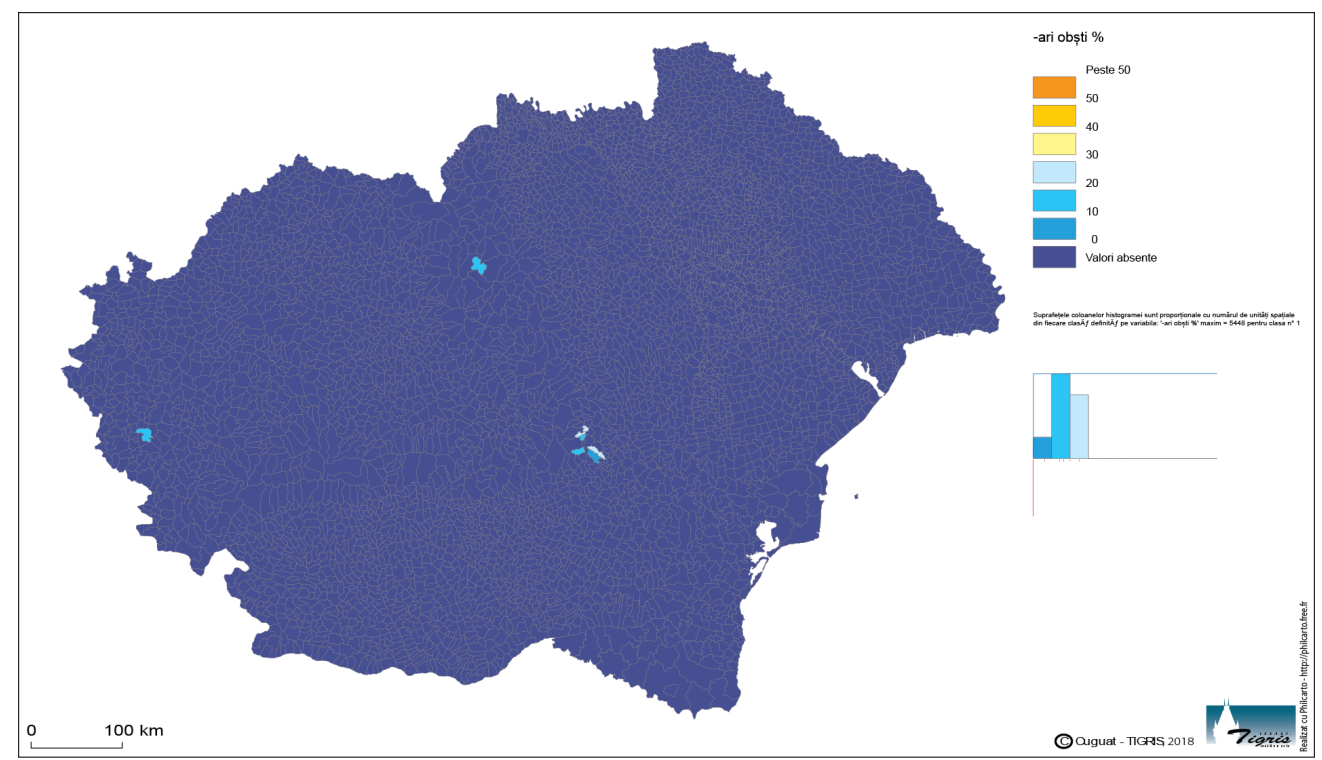

Figure 9: Distribution by counties of oikonyms with the suffix -ari, showing the development of settlements from communities of free peasants in the Romanian space.

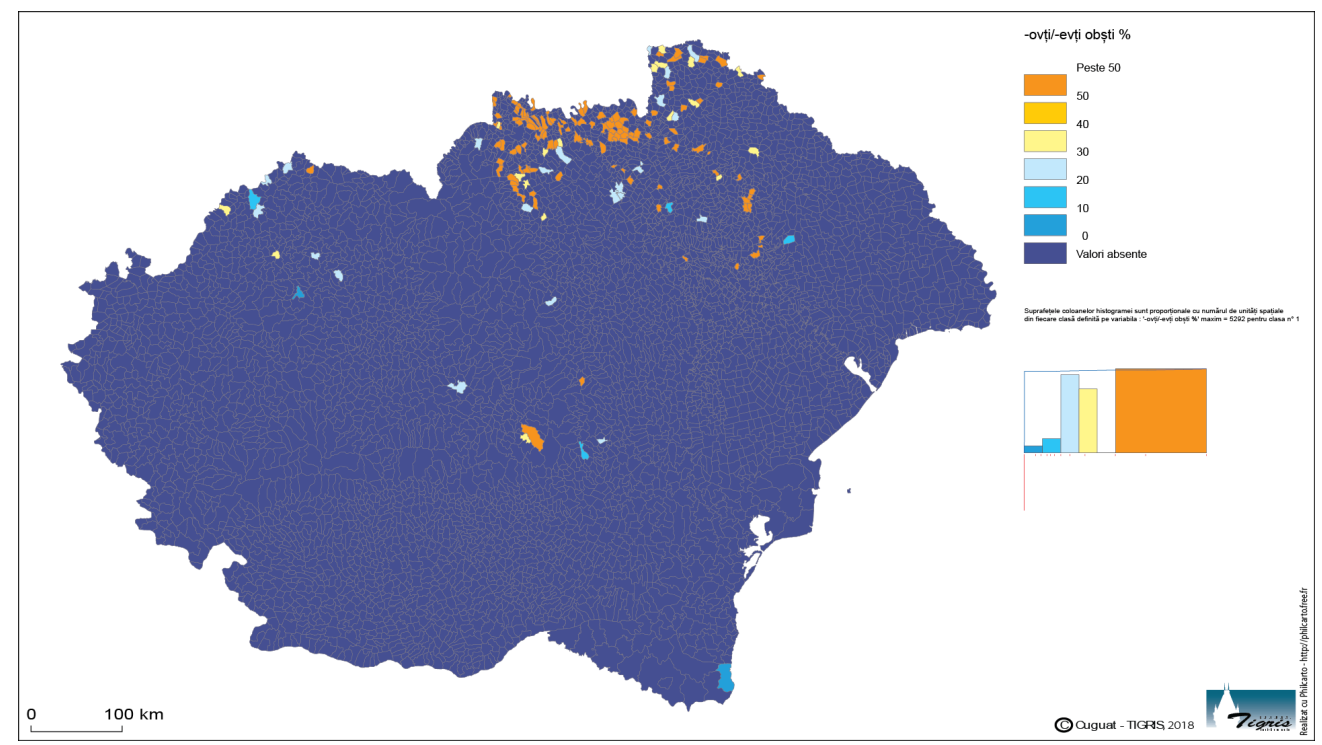

Figure 10: Distribution by counties of oikonyms with the suffixes - ovți/-evți, showing the development of settlements from communities of free peasants in the Romanian space.

The suffix -inți is more rare, retrieving only for 60 settlements $(0.3 \%)$, with a more isolated spatial localisation. It is observed in the northern extremities of Bukovina, Basarabia and Transnistria (Fig. 11), with an old and consistent Slavic (Ukrainian) influence.

We can obtain another proof of the age of the suffix - essti in Romanian, by analysing its singular version, $-e s c u$, frequently employed for the creation of patronyms, used today as family names. The list below is not exhaustive, but we have registered more than 100 such anthroponyms ${ }^{5}$, and with these we have made a map with the spatial distribution, at the World states level (Fig. 12). The map is made with

${ }^{5}$ We have registered the following names: Alexandrescu, Andreescu, Angelescu, Anghelescu, Antonescu, Avrămescu, Basarabescu, Bălănescu, Bărbulescu, Bobescu, Bogdănescu, Brătescu, Bucurescu, Călinescu, Chiriacescu, Chirilescu, Chirițescu, Comăn- 


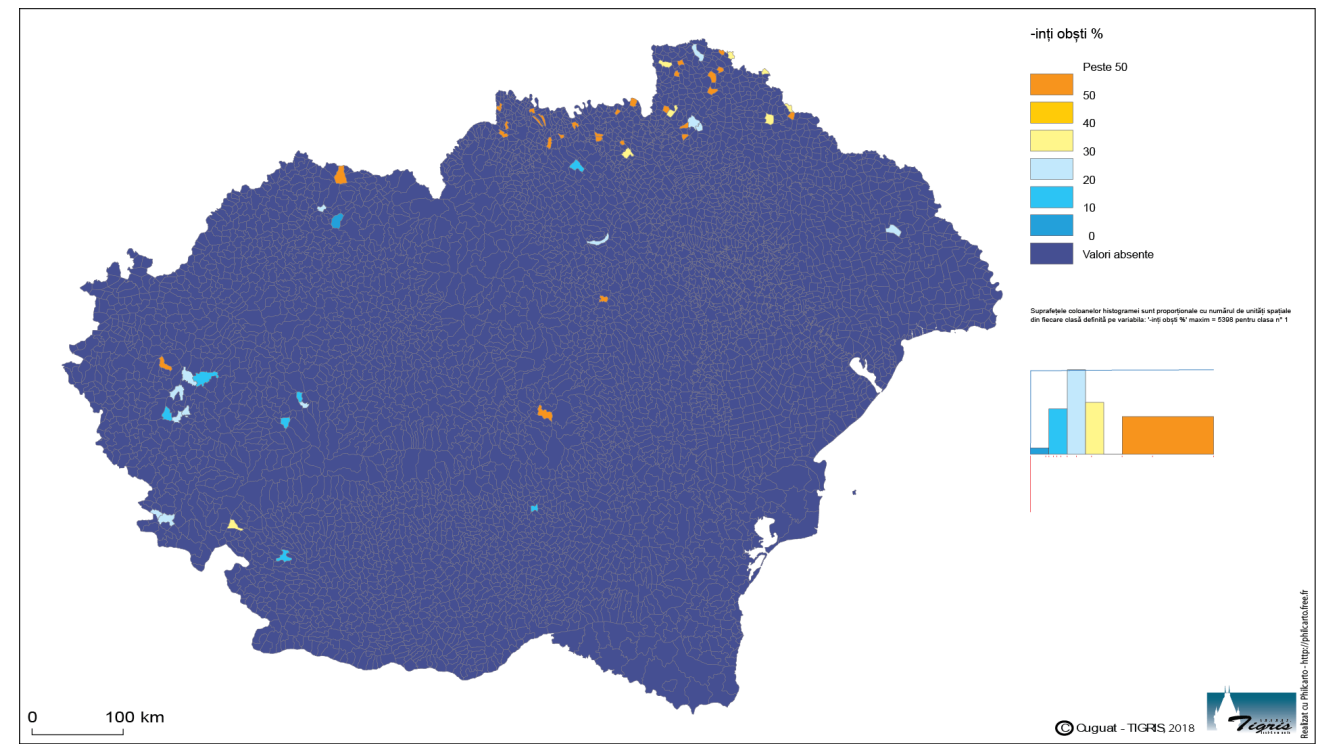

Figure 11: Distribution by counties of oikonyms with the suffix -inți, showing the development of settlements from communities of free peasants in the Romanian space.

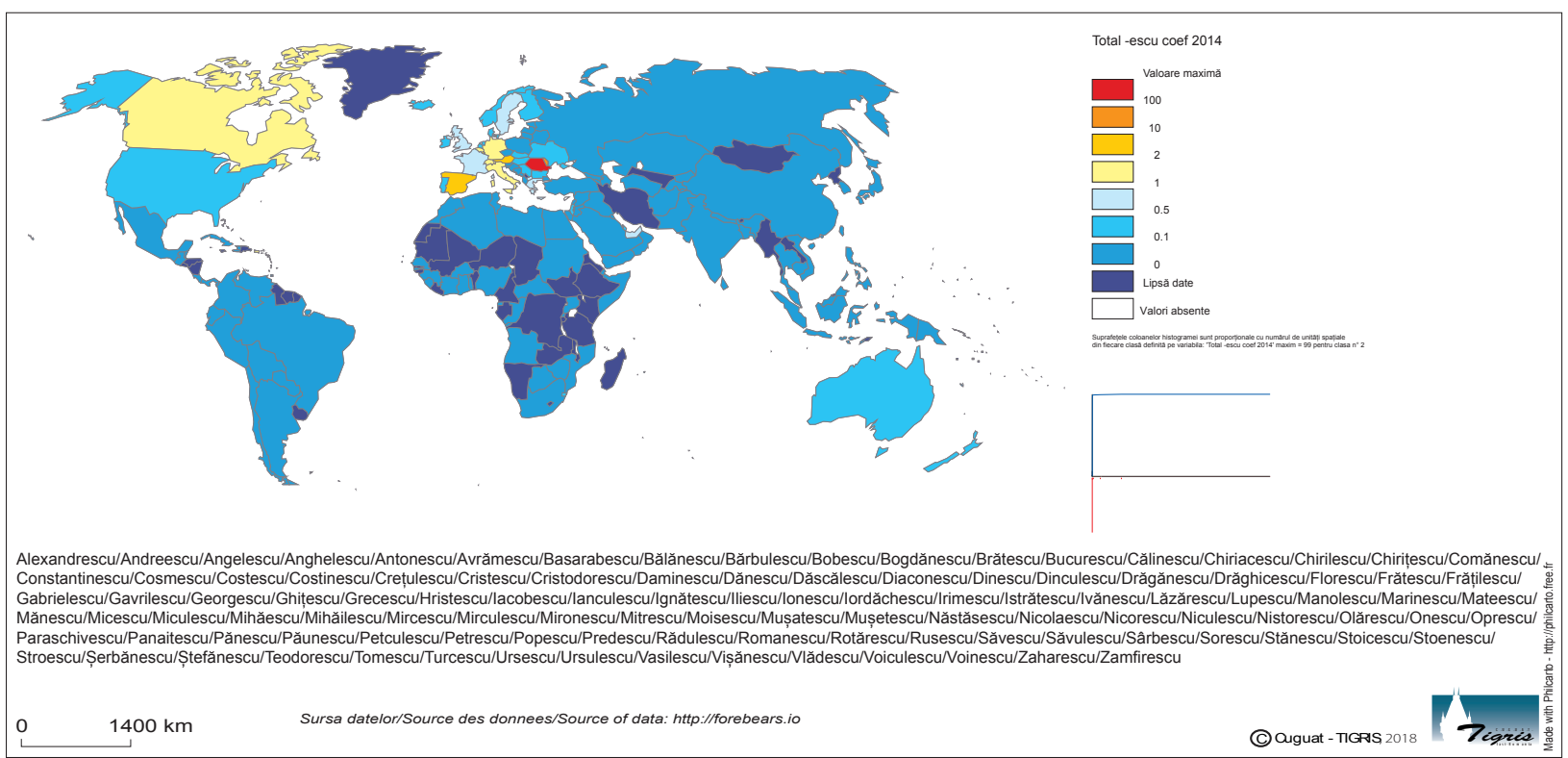

Figure 12: Distribution of bearers of names with the suffix - escu (2014). Spatial distribution coefficient.

the method of spatial distribution coefficient. If we analyse the spatial distribution, we observe that the countries with the biggest values of this coefficient are Romania and Republic of Moldova, the two states with Romanian as official language. In fact, the highest frequency is observed even as level of each name, in the majority of cases the big values being in Romania, but, sometimes, in Republic of Moldova (for example, in the case of name Micescu). Following the cultural "model" of Romanian migration, in the last

escu, Constantinescu, Cosmescu, Costescu, Costinescu, Crețulescu, Cristescu, Cristodorescu, Daminescu, Dănescu, Dăscălescu, Diaconescu, Dinescu, Dinculescu, Drăgănescu, Drăghicescu, Florescu, Frătescu, Frățilescu, Gabrielescu, Gavrilescu, Georgescu, Ghițescu, Grecescu, Hristescu, Iacobescu, Ianculescu, Ignătescu, Iliescu, Ionescu, Iordăchescu, Irimescu, Istrătescu, Ivănescu, Lăzărescu, Lupescu, Manolescu, Marinescu, Mateescu, Mănescu, Micescu, Miculescu, Mïӑеscu, Mihăilescu, Mircescu, Mirculescu, Mironescu, Mitrescu, Moisescu, Muşatescu, Mușetescu, Năstăsescu, Nicolaescu,Nicorescu, Niculescu, Nistorescu, Olărescu, Onescu, Oprescu, Paraschivescu, Panaitescu, Pănescu, Păunescu, Petculescu, Petrescu, Popescu, Predescu, Rădulescu, Romanescu, Rotărescu, Rusescu, Săvescu, Săvulescu, Sîrbescu, Sorescu, Stănescu, Stoicescu, Stoenescu, Stroescu, S,erbănescu, S,tefãnescu, Teodorescu, Tomescu, Turcescu, Ursescu, Ursulescu, Vasilescu, Vişănescu, Vlădescu, Voiculescu, Voinescu, Zaharescu, Zamfirescu. 
100 years, Romanian communities were in different countries, especially in Europe (Austria, Germany, Switzerland, Italy, Spain, Belgium), and, more rarely, in North America (Canada).

\section{Conclusions}

We can highlight some aspects: :

- The spatial distribution of the suffixes that prove the evolution of more settlements from big patriarchal communities highlights the amplitude and the old existence of the communities of free peasants, process that can be dated back to the first centuries of the Middle Ages, if not the end of Antiquity.

- The highest frequency of these suffixes - with a Romanian predominance, rarely Slavic-can be observed in the East and South of the Carpathians (first, in the historical Moldavia and in Wallachia), but also in other areas with a higher frequency in the West of the mountains.

- The most compact areas in which Slavic suffixes are present are the north of Bukovina, Bassarabia and Transnistria.

- The most frequent localisation of the patronymic suffix - escu is registered in the two Romanian States, from which numerous citizens have migrated to different countries, especially in Europe, and, rarely, in North America.

\section{Bibliography}

Constantinescu, N.A. (1963). Dicţionar onomastic românesc, Editura Academiei, București.

De Wulf, C. (1665-1729). Synodorum Generalium et Provincialium Decreta et Canones, Scholiis, Notis ac Historic, vol. I-XII, Albritius \& Coleti, Venezia.

Delehaye, H. et al. (1940). Propylaum ad Acta Sanctorum Decembris, Saint Michel, Bruxelles.

Le Quien, M. (1740). Oriens christianus in quatuorpatriarchatus digestus, in quo exhibentur Ecclesia patriarche ceterique presules totius Orientis, vol. I-III, Typographia Regia, Paris.

Mansi J.D. (1758-1798). Sacrorum Conciliorum nova et amplissima collectio, vol 1-53, Firenze-Venezia.

Moldovanu, D. (1970). Legile formative ale toponimelor românești cu radical antroponimic. I. Formaţii de plural, in "Anuar de Lingvistică și Istorie Literară”, XXI, p. 15-47.

Moldovanu, D. (coord.) (2014). Tezaurul Toponimic al României. Moldova, vol. II, part I, Editura Universității „Alexandru Ioan Cuza”, Iași.

Turcuș, Ș. (coord.) (2011). Antroponimia în Transilvania medievală (secolele XI-XIV). Evaluare statistică, evoluții, semnificații, vol. I, Editura Mega, Cluj.

Ungureanu, A. \& Boamfă, I. (2006). Toponomastică, SEDCOM Libris, Iași.

ancestry.com, 15.02-29.04.2016

catholic-bierarchy.org, 1.05-25.10.2017

dare.ht.lu.se, 18-21.04, 15-27.10.2017

documentacatholicaomnia.eu, 6-11.04.2017

fing.ac, 22.03-11.04.2017

forebears.io, 15.02-29.04.2016

heiligenlexikon.de, 1-7.05.2017

surnames.behindthename.com, 15.02-29.04.2016 